\title{
Analysis of Prices and Arrivals of Apple Fruit in Narwal Market of Jammu
}

\author{
Jahangir Ali*, Jyoti Kachroo, Deep Ji Bhat and Anil Bhat
}

Division of Agricultural Economics and ABM, Sher-e-kashmir University of Agricultural Sciences and Technology Jammu, Chatha-180009, India

*Corresponding author: jahangirdar64@gmail.com

\begin{abstract}
The present study was conducted with an intention to study the behavior of prices and arrivals of apple fruit in Narwal market of Jammu and also to estimate their trend. This study is based on the secondary data of one decade collected from Directorate of Horticulture, Planning and Marketing, Narwal, Jammu. Ten years monthly data i.e. from 2007-08 to 2016- 17 on prices and arrivals of apple have been utilized for modeling purpose. For analytical framework Linear Regression Equation were used to study the Trend of the time Series Data on prices and arrivals and seasonal indices were calculated to study the periodic movements in business activity which occur regularly every year and have their origin in the nature of the year itself. The results showed positive trend in both prices and arrivals of apple. Moreover the prices and arrivals are anticipated to increase at the rate of ₹ 220.06 per annum per quintal which is 15969.42 quintals of apple arrivals per year. The main season for arrivals of local as well as non-local apple from other regions and states in Narwal market was from August to January. Prices for apples were found lowest in the month of April (₹ 6707.00/qntls.) and contrary in the month of August with highest price rate (₹ 100892.50/qntls.). The seasonal indices of arrivals of apple in Narwal market were recorded maximum during the month of October (471.00) and minimum in the month of April (0.19). The seasonal index for prices being lowest in the month of April (0.19) and the highest in August (160.66).
\end{abstract}

Keywords: Trend, Prices, Arrivals, Time series, Seasonal variation, Jammu.

India is the world's $3^{\text {rd }}$ largest apple producing country behind China and the United States. Despite this, India faces a supply gap in its domestic apple market due to the increasing demand from the growing middle class. Following the trade liberalization in April 1999, apple imports into India have grown dramatically, reaching 186,387 metric tonnes valued at US $\$ 197$ million in 2012 from negligible imports of 20,093 metric tonnes ten years ago i.e. an increase of 827.62 per cent. The market shares of apples from the United States and China are 41 per cent and 31 per cent respectively, followed by Chile, New Zealand, Italy, and others. About 95 to 98 per cent of fresh apple imports enter the market through the ports of Mumbai or Chennai. Chennai's port caters to the states of Tamil Nadu, Karnataka, Odisha, Andhra Pradesh, and West
Bengal, while the port of Mumbai supplies the entire western and northern Indian market (Anonymous, 2013).

Jammu and Kashmir state is well known for its horticultural produce both in India and abroad. The production has increased from 17.13 lakh metric tonnes in 2009-10 to 21.17 lakh metric tonnes in 2013-14, recording an increase of 23.58 per cent. With regard to share of fresh and dry fruits production, it worked out to be 87.63 per cent and 12.36 per cent with 18.55 lakh metric tonnes and 2.62 lakh metric tonnes respectively. Apple ranks first with a share of 78.51 per cent followed by walnut with share of 11.89 per cent (Anonymous, 2013-14). Jammu and Kashmir is the major producer of apple and walnuts in India, 77 per cent of apple and 90 per cent of walnut production in India is covered 
by the state of Jammu and Kashmir. The percentage share of state in India's total production is showing an increasing trend because of such reasons the state has been declared as the "Agri. Export Zone for Apples and Walnuts"(Rather et al. 2013). Apple production is one of the important sources of revenue for the economy in Jammu and Kasshmir (J\&K). Apple cultivation in $\mathrm{J} \& \mathrm{~K}$ is fast expanding because apple has a comparative advantage over the other crops that can be grown in hilly regions (Bhat and Choure, 2014).

Apple is one of the major temperate fruits to be traded in the Narwal market of Jammu which accounts maximum of 775110 quintals in the year 2016-17. Narwal market was Categorically selected because being the only organized market in Jammu provinces dealing in the sale and purchase of fruits and vegetables. There are number of varieties of apple fruit which arrive to Narwal market for business, These varieties mostly include Red Dilicious, Golden delicious, Ambri, Kesri, Maharaji, American, razakwari and hazratbali. Most of the arrivals of apple fruit come from Kashmir valley including some amount of arrivals from temperate zone of Jammu region, followed by Himachal Pradesh and other apple producing states. The present study was conducted with an intention to study the behaviour of prices and arrivals of apple fruit over a period of time in Narwal market of Jammu. It was thought to have an idea of some regulated markets if available in Jammu region so that one could find the amount of apple fruit supplied by the growers of Jammu region and also imported from other states of India.

\section{MATERIALS AND METHODS}

The present study is based on the secondary data of one decade collected from Directorate of Horticulture, Planning and Marketing, Narwal, Jammu. Narwal is one of the terminal markets of Jammu and Kashmir for fruits and vegetables. Ten years monthly data i.e. from 2007-08 to 2016-17 on prices and arrivals of apple have been utilized for modeling purpose.

\section{Analytical Framework}

In order to achieve the objectives of the study, statistical techniques used in the analysis are as under:

\section{Seasonal fluctuations}

The steps involved in the construction of seasonal index were as follows:

1. Firstly data was arranged in months and years.

2. Then, Average $\bar{X}_{i^{\prime}}(i=1,2, \ldots \ldots ., 12)$ for the $i^{\text {th }}$ month for all the years. $\left[i^{\text {th }}\right.$ month, $i=$ $1,2, \ldots \ldots \ldots, 12$ represents January, February,....., December respectively.]

3. Average $X$ of the monthly averages, i.e., $\bar{X}=\frac{1}{12} \sum_{i=1}^{12} \bar{X} i$

4. Seasonal indices for different months are obtained by expressing monthly averages as percentage of $\bar{X}$. Thus, Seasonal index for $i^{\text {th }}$ month $=\left(\frac{\bar{X} i}{\bar{X}}\right) \times 100 ; i=1,2, \ldots . ., 12$.

Source : (Gupta and Kapoor, 2007)

\section{Linear trend}

In the present study, the Trend of the Time Series Data on prices and arrivals had been worked out, with the help of the Linear Regression Equation, since the prices and arrivals had exhibited a linear relationship with Time. The Trend Equation fitted for the price and arrivals of apple was:

$$
\mathrm{Y}=\mathrm{a}+\mathrm{b}_{\mathrm{t}}
$$

Where,

$\mathrm{Y}$ - Prices and arrivals of apple (Prices in ₹ per quintal and arrivals in quintals)

a - Constant

b - Slope (Regression Co-efficient)

$t$ - Time in Number of Years

Source: (Mercy. 2012)

\section{RESULTS AND DISCUSSION}

Seasonal variations are those periodic movements in business activity which occur regularly every year and have their origin in the nature of the year itself. Since these variations repeat during a period of 12 months they can be predicted fairly accurately. Nearly every type of business activity is susceptible to seasonal influence to a greater or lesser degree 
Table 1: Monthly averages of prices and arrivals of apple in Narwal market of Jammu (2007-08 to 2016-17)

\begin{tabular}{cccccc}
\hline S1. No. & Month & $\begin{array}{c}\text { Total Arrivals } \\
\text { (Qtls.) }\end{array}$ & $\begin{array}{c}\text { Monthly averages of } \\
\text { arrivals }\end{array}$ & $\begin{array}{c}\text { Total prices } \\
\text { (₹/qtl.) }\end{array}$ & $\begin{array}{c}\text { Monthly averages of } \\
\text { prices }\end{array}$ \\
\hline 1 & April & 1175.00 & 117.50 & 6707.00 & 670.70 \\
2 & May & 0.00 & 0.00 & 0.00 & 0.00 \\
3 & June & 0.00 & 0.00 & 0.00 & 0.00 \\
4 & July & 39245.00 & 3924.50 & 47519.50 & 4751.95 \\
5 & August & 186712.00 & 18671.20 & 100892.50 & 10089.25 \\
6 & September & 1133170.00 & 113317.00 & 77632.00 & 7763.20 \\
7 & October & 2854530.00 & 285453.00 & 88352.50 & 8835.25 \\
8 & November & 1349239.00 & 134923.90 & 91503.00 & 9150.30 \\
9 & December & 362203.00 & 36220.30 & 97167.00 & 9716.70 \\
10 & January & 102650.00 & 10265.00 & 60787.50 & 6078.75 \\
11 & February & 22055.00 & 2205.50 & 39681.00 & 3968.10 \\
12 & March & 9580.00 & 958.00 & 17746.00 & 1774.60 \\
\hline
\end{tabular}

Note: 1 . Simple average was used to find out monthly arrivals; 2. Missing values were excluded from calculations; 3.The months with no arrivals were excluded from the calculation.

Source: Directorate of Horticulture, Planning and Marketing, Narwal, Jammu

and as such these variations are regarded as normal phenomenon recurring every year.

Seasonal variation in the arrivals and prices of apple fruit in the secondary market is a well known phenomenon. Climatic conditions as well as human and institutional factors influence the market arrivals, very low bargaining power of the cultivators, lack of storage facility and high perishability of fruit and pressing demand for ready cash and ignorance of the market information force the cultivators to sell their produce immediately after harvest. It was observed that the produce brought to the market after the harvest was treated as of better quality because of low keeping quality and farmers receive better price.

In Jammu region there is not a single regulated market, though Narwal Market is not a regulated market but is a well organised market, therefore Narwal market was selected to have an idea about the supply and price of apple fruit. The average monthly arrivals and prices for the period of last ten years i.e. 2007-08 to 20016-17 are shown in Table 1.

Table 1 indicated the average monthly arrivals and prices of apple in Narwal market of Jammu for the period of 2007-08 to 2016-17. It depicted that the highest market arrivals of apple in Narwal market were recorded during the month of October
(2854530.00 qntls.) and lowest in April (1175.00 qntls.). However, the main season for arrivals of local as well as non-local apple from other states in Narwal market was from August to January. Prices for apples were found lowest in the month of April (₹ 6707.00/qntls.) and contrary in the month of August with highest price rate (₹ 100892.50/qntls.). The tables also show that there was neither local nor import of apple during the months of May and June.

\section{Seasonal fluctuation in prices and arrivals of apple fruit}

Tables 2 depicted the seasonal indices of arrivals and prices of apple fruit in Narwal market of Jammu and revealed that indices of arrivals of apple in Narwal market were recorded maximum during the month of October (471.00) and minimum in the month of April (0.19). The arrivals started picking up from the month of June onwards to the end of April. The prices moved slightly opposite to the arrivals for the month of August and had remained constant in the month of April. The seasonal index for prices being lowest in the month of April (0.19) and the highest in August (160.66) which would be considered favorable for traders to supply their produce in the same month to receive remunerative prices for their produce. 
Table 2: Seasonal indices of apple prices and arrivals in Narwal market of Jammu (2007-08 to 2016-17)

\begin{tabular}{cccc}
\hline $\begin{array}{c}\text { Sl. } \\
\text { No. }\end{array}$ & Month & $\begin{array}{c}\text { Seasonal Indices of } \\
\text { prices }\end{array}$ & $\begin{array}{c}\text { Seasonal Indices } \\
\text { of Arrivals }\end{array}$ \\
\hline 1 & April & 10.68 & 0.19 \\
2 & May & 0.00 & 0.00 \\
3 & June & 0.00 & 0.00 \\
4 & July & 75.67 & 6.48 \\
5 & August & 160.66 & 30.81 \\
6 & September & 123.62 & 186.97 \\
7 & October & 140.69 & 471.00 \\
8 & November & 145.71 & 222.63 \\
9 & December & 154.73 & 59.76 \\
10 & January & 96.80 & 16.94 \\
11 & February & 63.19 & 3.64 \\
12 & March & 28.26 & 1.58 \\
\hline
\end{tabular}

Note: 1 . Missing values in data were excluded from calculations.

Source: Author's calculation

\section{Trend analysis}

Trend was the basic tendency of the prices and arrivals of apple to increase or decrease over a period of time. It described the pattern and behavior of the prices and arrivals of apple which had been characterized by the series of Data recorded in the past.

To identify the Trend in the arrivals of apple in the Narwal Market for the period 2007-08 to 20016-17, the Linear Regression Equation had been fitted and the estimated Trend Function was,

$$
\begin{gathered}
\mathrm{Y}=518224.07+15969.42^{*}(\mathrm{t}) \\
(70959.86)(11436.22) \\
\mathrm{R}^{2}=0.195
\end{gathered}
$$

Figures in parenthesis denote Standard Errors.

*Insignificant.

It could be observed from the Function that the Co-efficient of Determination $\left(\mathrm{R}^{2}\right)$ was 0.195 which had indicated that 0.195 per cent of the variations in the arrivals of apple had been explained by the independent Variable time (t). The Results had also shown that there had been a significant increase in the arrivals of apple over a period of Years. The Annual Average Arrivals of Apple had increased at the amount of 15969.42 Quintals per year. The Actual arrivals Series with the Estimated Trend Value is presented in Table 3 and has been plotted in the Fig. 2.1.
Table 3: Trend in arrivals of apple fruit in Narwal Market of Jammu

\begin{tabular}{ccc}
\hline Year(t) & $\begin{array}{c}\text { Actual arrivals } \\
\text { (Quintals) }\end{array}$ & $\begin{array}{c}\text { Predicted arrivals } \\
\text { (Quintals) }\end{array}$ \\
\hline $2007-08$ & 670258 & 534193.49 \\
$2008-09$ & 426895 & 550162.92 \\
$2009-10$ & 510417 & 566132.34 \\
$2010-11$ & 562757 & 582101.76 \\
$2011-12$ & 715985 & 598071.19 \\
$2012-13$ & 566910 & 614040.61 \\
$2013-14$ & 580876 & 630010.04 \\
$2014-15$ & 716551 & 645979.46 \\
$2015-16$ & 534800 & 661948.88 \\
$2016-17$ & 775110 & 677918.31 \\
\hline
\end{tabular}

Note: 1 . Missing values in data were excluded from calculations; Source: Directorate of Horticulture, Planning and Marketing, Narwal, Jammu

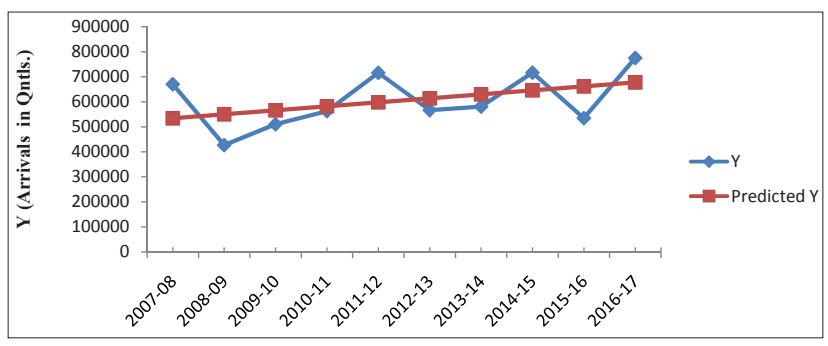

Fig. 2.1: Estimated trend in Arrivals of apple

To identify the Trend in the prices of apple in the Narwal Market for the period 2007-08 to 20016-17, the Linear Regression Equation had been fitted and the estimated Trend Function was:

$$
\begin{gathered}
\mathrm{Y}=4022.90+220.06^{*}(\mathrm{t}) \\
(977.90)(157.60) \\
\mathrm{R}^{2}=0.195
\end{gathered}
$$

Figures in parenthesis denote Standard Errors; ${ }^{*}$ Insignificant.

It could be observed from the Function that the Co-efficient of Determination $\left(\mathrm{R}^{2}\right)$ was 0.195 which had indicated that 0.195 per cent of the variations in the prices of apple had been explained by the independent variable time ( $\mathrm{t})$. The Results had also shown that there had been a significant increase in the prices of apple over a period of Years. The Annual Average prices of Apple per quintal had increased at the rate of ₹ 220.06 per annum. The Actual price Series with the Estimated Trend Value is presented in Table 4 and has been plotted in the Fig. 2.2. 
Table 4: Trend in prices of apple fruit in Narwal Market of Jammu

\begin{tabular}{ccc}
\hline Year(t) & $\begin{array}{c}\text { Actual Prices } \\
\text { (₹/Quintals) }\end{array}$ & $\begin{array}{c}\text { Predicted prices } \\
\text { (₹/Quintals) }\end{array}$ \\
\hline $2007-08$ & 5843.92 & 4242.96 \\
$2008-09$ & 4880.17 & 4463.02 \\
$2009-10$ & 5286.33 & 4683.08 \\
$2010-11$ & 2962.08 & 4903.14 \\
$2011-12$ & 3479.42 & 5123.20 \\
$2012-13$ & 4267.58 & 5343.26 \\
$2013-14$ & 6789.21 & 5563.33 \\
$2014-15$ & 5377.25 & 5783.39 \\
$2015-16$ & 5337.50 & 6003.45 \\
$2016-17$ & 8108.88 & 6223.51 \\
\hline
\end{tabular}

Note: 1. Missing values in data were excluded from calculations; Source: Directorate of Horticulture, Planning and Marketing, Narwal, Jammu.

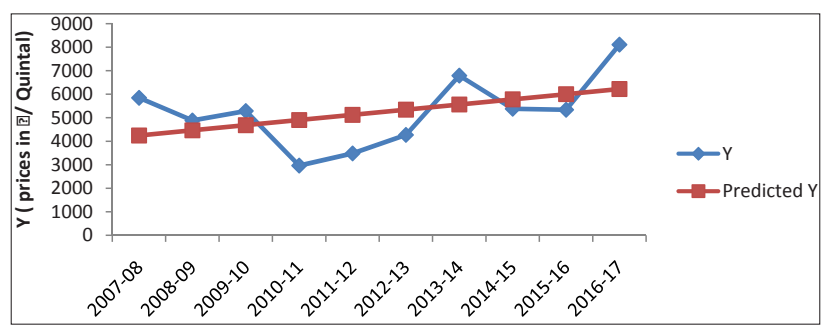

Fig. 2.2: Estimated trend in prices of apple

\section{CONCLUSION}

The results showed positive trend in both prices and arrivals of apples in Narwal market of Jammu. Moreover, the prices and arrivals were anticipated to increase at the rate of ₹ 220.06 per annum per quintal which is 15969.42 quintals of apple arrivals per year. The main season for arrivals of local as well as non-local apple from other regions and states in Narwal market was from August to January. Prices for apples were found lowest in the month of April (₹ 6707.00/qntls.) and contrary in the month of August with highest price rate (₹ 100892.50/Qntls.). The seasonal indices of arrivals of apple in Narwal market were recorded maximum during the month of October (471.00) and minimum in the month of April (0.19). The seasonal index for prices being lowest in the month of April (0.19) and the highest in August (160.66).

\section{REFERENCES}

Anonymous, 2013. Global Agricultural Information Network. USDA Foreign Agricultural service. Retrieved on 15 sep. 2014 from www.2013 Apple ProductBrief_New Delhi_India_6-19-2013.pdf.

Anonymous, 2013-14. J\&K planning commission. J\&K. Retrieved on 15 sep. 2014from www.jandkplanning.com images_economicsurvey2014_EconomicSurvey2014.pdf

Bhat, T. M. and Choure, T. 2014. Status and Strength of Apple Industry in Jammu and Kashmir. International Journal of Research, 1(4): 277-283

Gupta, S.C. and Kapoor, V.K. 2007. Fundamentals of applied statistics . pp. 2.2-2.9. Sutan chand \& sons, New Delhi.

Mercy, N.M.F. 2012. Production and Marketing of food crops - A study with special reference to guava in dindigul district. Ph.D thesis. Mother Teresa Women's University, Kodaikanal, India.

Rather, N.A., Lone, P. A., Reshi, A.A. and Mir, M.M. 2013. An Analytical Study on Production and Export of Fresh and Dry Fruits in Jammu and Kashmir. International Journal of Scientific and Research Publications, 3(2):1-7.

Directorate of Horticulture, Planning and Marketing, Narwal, Jammu. 
